\title{
Divergent selection on milk somatic cell count in goats improves udder health and milk quality with no effect on nematode resistance
}

\author{
R. Rupp, ${ }^{1 *}$ C. Huau, ${ }^{1}$ H. Caillat, ${ }^{1}$ T. Fassier, ${ }^{2}$ F. Bouvier, ${ }^{2}$ E. Pampouille, ${ }^{1}$ V. Clément,,${ }^{1,3}$ I. Palhière, ${ }^{1}$ \\ H. Larroque, ${ }^{1}$ G. Tosser-Klopp, ${ }^{1}$ P. Jacquiet, ${ }^{4}$ and P. Rainard ${ }^{5}$ \\ ${ }^{1}$ Génétique, Physiologie et Système d'Elevage (GenPhySE), Université de Toulouse, INRA, ENVT, Castanet Tolosan, F-31326, France \\ ${ }^{2}$ Domaine de Bourges, INRA, Osmoy, F-31326, France \\ ${ }^{3}$ Institut de l'Elevage, Castanet Tolosan, F-31326, France \\ ${ }^{4}$ Interactions Hôtes-Agents Pathogènes (IHAP), Université de Toulouse, INRA, INPT, ENVT, Toulouse, F-131076, France \\ ${ }^{5}$ Infectiologie et santé publique (ISP), INRA, Université Tours, Nouzilly, F-37380, France
}

\section{ABSTRACT}

Milk somatic cell count (SCC) is commonly higher in goats than in cattle and sheep. Furthermore, the ability of milk SCC to predict mastitis is considered lower in goats than in cattle and sheep, and the relevance of somatic cell score (SCS)-based selection in this species has been questioned. To address this issue, we created 2 divergent lines of Alpine goats using artificially inseminated bucks with extreme estimated breeding values for SCS. A total of 287 goats, 158 in high- and 129 in low-SCS lines, were scrutinized for mastitis infections. We subjected 2,688 milk samples to conventional bacteriological analyses on agarose and bacterial counts were estimated for positive samples. The SCS, milk yield, fat content, and protein content were recorded every 3 wk. Clinical mastitis was systematically noted. A subset of 40 goats (20 from each line) was subsequently challenged with Haemonchus contortus and monitored for anemia (blood packed cell volume) and fecal egg counts to see if SCS-based selection had an indirect effect on resistance to gastrointestinal nematodes. Milk production traits, including milk quantity, fat content, and protein content, were similar in both goat lines. In contrast, the raw milk SCC almost doubled between the lines, with $1,542,000$ versus 855,000 cells $/ \mathrm{mL}$ in the high- and low-SCS lines, respectively. The difference in breeding value for SCS between lines was 1.65 genetic standard deviation equivalents. The Staphylococcus spp. most frequently isolated from milk were $S$. xylosus, $S$. caprae, S. epidermidis, and S. aureus. The frequency of positive bacteriology samples was significantly higher in the high-SCS line (49\%) than in the low-SCS line (33\%). The highest odds ratio was 3.49 (95\% confidence

Received September 7, 2018.

Accepted January 11, 2019.

*Corresponding author: rachel.rupp@inra.fr interval: 11.95-6.25) for $S$. aureus. The distribution of bacterial species in positive samples between lines was comparable. The average quantity of bacteria in positive samples was also significantly higher in high-SCS goats (69 \pm 80 growing colonies) than in low-SCS goats (38 \pm 62 growing colonies). Clinical cases were rare and equally distributed between high- $(\mathrm{n}=4 ; 2.5 \%)$ and low-SCS ( $\mathrm{n}=3 ; 2.3 \%)$ lines. Furthermore, the larger the amounts of bacteria in milk the higher the SCS level. Conversely, goats with repeatedly culture-negative udders exhibited the lowest SCC levels, with an average of below 300,000 cells $/ \mathrm{mL}$. We therefore confirmed that SCS is a relevant predictor of intramammary infection and hygienic quality of milk in goats and can be used for prophylactic purposes. After challenge with $H$. contortus, goats were anemic with high fecal egg counts but we found no difference between the genetic lines. This result provides initial evidence that resistance to mastitis or to gastrointestinal nematodes infections is under independent genetic regulation. Altogether, this monitoring of the goat lines indicated that SCS-based selection helps to improve udder health by decreasing milk cell counts and reducing the incidence of infection and related bacterial shedding in milk. Selection for low SCC should not affect a goat's ability to cope with gastrointestinal nematodes.

Key words: mastitis, divergent selection, dairy goat, gastrointestinal nematodes

\section{INTRODUCTION}

Mastitis is a serious problem in dairy breeding systems. In goats, as in small ruminants in general, mastitis is the primary sanitary cause of involuntary culling; clinical mastitis is rare $(<5 \%)$, but the prevalence of subclinical mastitis is 20 to $30 \%$ per lactation (Bergonier et al., 2003). Based on conservative assumptions of a $10 \%$ incidence of infectious mastitis in European Union dairy goat herds, Rupp and Foucras (2010) estimated 
the annual losses due to milk reduction in mastitic animals (20\% in affected animals) to be in the region of $€ 60$ million per annum. High hygienic quality of milk is all the more important to goat breeders and the industry, as a large proportion of the milk is destined for specific high-quality markets, such as dietetic milks (lower amount of long-chain fatty acids than cow milk) and fresh or ripened cheeses (Duboeuf et al., 2004). However, some of the classical prophylactic measures to control mastitis can seem inefficient or too demanding to breeders because of the large size of herds, which makes complementary strategies more attractive.

In many countries, resistance to mastitis in cattle and sheep has been included in the breeding objectives, the aim being to improve the animals' health and welfare, the hygienic quality of milk products, and overall efficiency and resilience (Heringstad et al., 2000; Rupp et al., 2002; Miglior et al., 2005). Milk SCC, or often the log-derived SCS (Ali and Shook, 1980), is commonly used as a proxy for selection because the trait is heritable and easily measured on a large scale as part of the milk recording process. In dairy cattle, clinical mastitis is also used for selection purposes. Selection strategies are based on a linear decrease of milk SCS, ideally as a tool to decrease IMI. In dairy goats, heritability of SCS has been recently estimated to be around 0.20 (Rupp et al., 2011), indicating the feasibility of such selection in this species.

Nevertheless, controversy endures about the use of milk SCC to select for improved mastitis resistance (Rainard et al., 2018a). Whereas a consensus exists regarding selection against high SCC, opinions diverge regarding selection for excessively low SCC levels. Milk SCC in goats is commonly higher than in cattle and sheep (Contreras et al., 2007). Furthermore, the ability of milk SCC to predict IMI may be lower in goats than in cattle and sheep, as many environmental factors can increase SCC in the uninfected halves (Poutrel and Lerondelle, 1983; Boettcher et al., 2005; Contreras et al., 2007; Jiménez-Granado et al., 2014). This has raised the question of whether milk SCC is an efficient selection criterion for reducing IMI.

Another question raised is whether genetic selection for improved resistance to mastitis can have a reverse effect on the animal's resistance to other diseases. Indeed, mastitis is mainly caused by extracellular bacteria, and the host's resistance probably involves a crucial role of type-1 immune response. However, the immune response activates different effectors and pathways depending on the nature of the invading microbes. For instance, the control of parasites is predominately governed by a type- 2 immune response. In addition, divergent selection experiments in mice (Mouton et al., 1984), pigs (Crawley et al., 2005), and poultry (Pinard-van der Laan, 2002) showed that resistance to various diseases and pathogens, and the different components of the immune response were, at least in part, under independent genetic regulation. In dairy farming, infestation with gastrointestinal nematodes is considered almost as important as mastitis with respect to the industry and public concern, economic impact, and animal welfare (Waller, 2006; Davies et al., 2009), especially in pasture-based production systems. However, the control of gastrointestinal nematodes with anthelmintics in the goat industry is seriously threatened by the development of anthelmintic-resistant parasites (Chartier et al., 2001). It is therefore important to verify that selection for improved resistance to mastitis does not deteriorate resistance to gastrointestinal nematodes.

The first aim of our study was to assess the efficiency of SCS-based selection to reduce IMI and improve milk hygienic quality. The experiment was based on a divergent selection of Alpine dairy goats. This paper describes the experimental design and survey of 287 goats. The second objective was to see if SCS-based selection had an indirect effect on resistance to gastrointestinal nematodes. This question was addressed by experimentally challenging 2 groups of 20 goats from the high- and low-SCS lines with Haemonchus contortus.

\section{MATERIALS AND METHODS}

The experiment was carried out in agreement with French National Regulations for the humane care and use of animals for research purposes. Animals were bred at the experimental INRA Farm (La Sapinière, Osmoy, France), which has the experimental approval C18-174-01.

\section{Animals}

Alpine dairy goats were from a divergent selection experiment based on EBV for milk cell counts of AI progeny-tested bucks. The experiment was initiated in 2008 at the INRA experimental facility of Bourges (Domaine de Galles, Avord, France). Birth year ranged from 2009 to 2015 and goats were monitored until 2016.

The individual EBV of sires were computed at the French population level using data from the national goat database of the CTIG (Processing Centre of Genetic Information, Jouy en Josas, France). The trait was the lactation mean of somatic cell scores (LSCS), with SCS $=3+\log _{2}(\mathrm{SCC} / 100,000)$ (Ali and Shook, 1980), adjusted for lactation stage and measured dur- 
ing the first 3 lactations (250 DIM) of the daughters, as described previously (Rupp et al., 2011). We used 1,922,459 lactations of 915,795 Alpine goats in 2016 to calculate the EBV. The EBV for LSCS were computed using a BLUP repeatability animal model. The model included the following fixed effects: herd by parity and year, age at kidding by year, and region and month of kidding by year and region (Larroque et al., 2011). The model also included the dry period length by year and region combination for parities 2 and 3 . The EBV for LSCS are expressed as genetic standard deviation $\left(\sigma_{\mathrm{g}}=\right.$ $0.548)$ multiplied by 10 and centered on the value 100 , reversing the sign so that EBV above 100 are desirable (low cell counts) whereas low values are undesirable (high cell counts). The EBV for the LSCS of AI bucks were first officially provided to breeders by the breeding organization (Capgenes, Mignaloux, France) in 2013. To reproduce the high- and low-SCS lines of divergent goats, we used 60 bucks with reliable (reliability $\geq 0.80$ ) and extremely unfavorable or favorable EBV for LSCS (Table 1). On average, the difference between the highand low-SCS sire LSCS EBV was 26.4, which corresponds to 2.64 genetic standard deviation equivalents. Sires of the 2 lines were also required to show similar and favorable EBV for milk production traits to avoid confounding effects from an indirect response to selection for production traits (Table 1).

Each year, 2 groups of 5 bucks were mated by AI, and about 15 goats each and 558 female offspring were obtained. The goats were inseminated at about 7 mo of age. Finally, 287 goats, 158 in the high-SCS line and 129 in the low-SCS line, started their first lactation at the INRA experimental facility between 2010 and 2016 . Each high- or low-SCS buck sired $4.8 \pm 2.7$ daughters, on average, with a range from 1 to 14 . Among the 287 goats, 176 and 108 completed a second and third lactation, respectively, during the same period.

Goats in both lines were housed together in the same facility and managed identically. The ration was based on lucerne hay and the goats were bred indoors all year around. Kidding was seasoned and occurred in January until early February. Goats were machine-milked twice a day with a DeLaval milking machine (DeLaval France, Elancourt, France) in a Rotolactor parlor (Eurl Gabard Systeme, Moutiers-Sous-Argenton, France) for 7 mo until October and were then dried off for 3 mo. Feeding, machine milking, and housing were totally representative of the regional breeding systems in western France. No voluntary culling of these animals took place during lactation or at drying off during this period (up to the end of third lactation).

\section{SCC, Milk Production, and Milk Bacteriological Examination}

Measurements of SCS, milk yield, fat content (FC), and protein content (PC) were recorded as part of the official milk records for the herd. Milk production and SCC were measured every 3 wk (except in August) over a 270-d lactation period (i.e., at 8 to 10 time points per animal). Both udder half milk samples and composite milk samples from each goat at morning milking were used to determine the SCC by Fossomatic cell counter (Foss Electric, Hillerød, Denmark) at the Interprofessional milk analysis laboratory LILCO (Laboratoire Interprofessionnel Laitier du Centre Ouest, Surgères, France).

Milk samples were taken from first-parity goats for bacteriological examination. Samples were collected aseptically from individual udder halves at the begin-

Table 1. Estimated breeding values [mean (SD)] for lactation mean SCS (LSCS) and production traits for 60 bucks that sired the high- and low-SCS lines

\begin{tabular}{|c|c|c|c|}
\hline Trait & $\begin{array}{l}\text { High-SCS line bucks } \\
\text { (high cell count) }\end{array}$ & $\begin{array}{l}\text { Low-SCS line buck } \\
\text { (low cell count) }\end{array}$ & Contemporary bucks $^{1}$ \\
\hline $\begin{array}{l}\text { No. of bucks } \\
\text { EBV for LSCS } \\
\text { Reliability of LSCS EBV } \\
\text { EBV for CPI }{ }^{2} \\
\text { EBV for milk quantity } \\
\text { EBV for protein content } \\
\text { EBV for fat content } \\
\text { EBV for protein yield } \\
\text { EBV for fat yield }\end{array}$ & $\begin{array}{l}32 \\
86.9(6.7)^{\mathrm{a}} \\
94(4) \\
104.7(16.3)^{\mathrm{a}} \\
17.3(52.4)^{\mathrm{a}} \\
0.01(1.26)^{\mathrm{a}} \\
-0.41(2.51)^{\mathrm{a}} \\
0.48(1.31)^{\mathrm{a}} \\
0.23(1.82)^{\mathrm{a}}\end{array}$ & $\begin{array}{l}28 \\
113.3(4.7)^{\mathrm{b}} \\
94(3.9) \\
108.1(21.9)^{\mathrm{a}} \\
20.5(68.6)^{\mathrm{a}} \\
-0.06(1.20)^{\mathrm{a}} \\
0.52(1.87)^{\mathrm{a}} \\
0.56(1.86)^{\mathrm{a}} \\
1.10(2.07)^{\mathrm{a}}\end{array}$ & $\begin{array}{l}1,043 \\
\quad 99.4(7.6)^{\mathrm{c}} \\
\quad 86(7) \\
84.5(28.6)^{\mathrm{b}} \\
-41.5(80.6)^{\mathrm{b}} \\
\quad 0.04(1.37)^{\mathrm{a}} \\
-0.03(2.23)^{\mathrm{a}} \\
-1.27(2.26)^{\mathrm{b}} \\
-1.47(2.79)^{\mathrm{b}}\end{array}$ \\
\hline
\end{tabular}

${ }^{\mathrm{a}-\mathrm{c}}$ Lowercase letters indicate significant differences in the EBV between lines. Significant differences were determined by $t$-test at $P<0.001$ from a model including birth year and line as fixed effects

${ }^{1}$ Contemporary bucks were all Alpine bucks born in the same years (1999-2010) with EBV for SCS and reliability of SCS EBV above 0.80 (excluding the high and low line bucks).

${ }^{2} \mathrm{CPI}=$ combined production index $=$ protein yield +0.4 protein content +0.2 fat yield +0.1 fat content. 
ning of morning milking. Samples were taken at 9 time points: just after lambing (and before the first suckling) and then concomitantly with monthly SCC samples (the day before). We gathered 2,688 samples over 4 yr (2010-2013). Milk bacteriological analyses (BAC) were performed at the Laboratory LDA8 (Laboratoire Départemental du Cher, Bourges, France) using conventional techniques on agarose, as described previously (Rupp et al., 2009). The results were expressed as a binary trait: positive or negative (0 or 1$)$. In addition, the bacteria in positive samples $(\mathrm{n}=1,141)$ were roughly quantified by counting the colonies and grouping them into 3 categories: few $(1-10, \mathrm{n}=477)$, moderate $(11-100, \mathrm{n}=404)$, and numerous $(>100, \mathrm{n}$ $=260$ ). To further exploit the BAC results, the udders were classified according to the presence and severity of infections. The classification into healthy glands and mild, severe, and very severe infections is detailed in Figure 2.

Clinical mastitis cases were systematically recorded by experienced technicians. Detection was based on the association of general symptoms (fever, exhaustion, loss of appetite) with local signs. The latter were usually observed at milking: color or consistency of modified milks and hot, swollen or painful udders.

\section{Challenge with the Gastrointestinal Nematode Haemonchus contortus}

Two groups of 20 high- and 20 low-SCS goats in second parity were challenged twice with a gastrointestinal nematode at approximately 90 and 140 DIM. All goats were infected simultaneously on the same day (d 0) with 5,000 Haemonchus contortus infective larvae (Humeau strain). All goats were treated with oral ivermectin (Oramec $0.2 \mathrm{mg} / \mathrm{kg}$, Merial SAS, Lyon, France) at $\mathrm{d} 35$. After a waiting period of $15 \mathrm{~d}$, the goats were reinfected with $5,000 \mathrm{H}$. contortus infective larvae (second d 0). This protocol was set to induce an adaptive immune response that is initiated with the first challenge and measured after the second challenge (Lacroux et al., 2006). Fecal samples were collected after each challenge at d 21, 28, and 35. Fecal egg counts (FEC) were assessed using a modified McMaster method for rapid determination (Raynaud et al., 1970). Blood samples were collected after each challenge at d 7, 14, 21, 28, and 35. Blood samples were collected in EDTA-coated tubes and packed cell volume (PCV) values were determined individually by centrifugation in microhematocrit tubes with a relative centrifugal force of 9,500 at room temperature for $10 \mathrm{~min}$ (Biofuge Hemo, Heraeus, Hanau, Germany).

\section{Statistical Analyses}

Linear mixed models (PROC MIXED, SAS version 9.4, SAS Institute Inc., Cary, NC) were used to evaluate the effect of line on the different repeated continuous traits pertaining to SCS, BAC, milk quantity and content, and response to nematodes challenge.

The following regression model was used for all traits:

$$
\mathbf{y}=\mathbf{X} \beta+\mathbf{Z a}+\mathbf{e},
$$

where $\mathbf{y}$ is the vector of the measured test-day SCS, milk yield, FC, PC, FEC (log-transformed), PVC, $\mathrm{BAC}$, and $\mathrm{BAC}$ quantity; $\beta$ is the solution for fixed effects; $a$ is the random animal effect; and $\mathbf{e}$ is the random vector of residual effects. $\mathbf{X}$ and $\mathbf{Z}$ are the incidence matrices linking phenotypic measurements to fixed effects $\beta$ and subjects a, respectively. It is assumed that a $\sim N(0, \mathbf{G})$, where $\mathbf{G}$ is the subject covariance matrix $\left(\mathbf{G}=\sigma_{a}^{2} \mathbf{I}\right)$ and $\mathbf{e} \sim N(0, \mathbf{R})$, where $\mathbf{I}$ is the identity matrix and $\mathbf{R}$ is the residual covariance matrix. Accordingly, $\operatorname{var}(\mathrm{y})=\mathbf{Z G} \mathbf{Z}^{\prime}+\mathbf{R}$.

For the dependent variables SCS, milk yield, FC, and $\mathrm{PC}$, the fixed effects were line, parity, and sampling time point within the year (67 levels). The correlated structure of data arising from longitudinal measurements ( $8-10$ sampling time points) on successive lactations (1-3 parity) was fitted with a direct product firstorder autoregressive covariance structure within parity.

For the dependent variables BAC and BAC quantity, measured only in first lactation, the fixed effects were line and sampling time point within the year (32 levels). The correlated structure of data arising from longitudinal measurements (5 to 9 sampling time points) on the 2 udder halves was fitted with a direct product first-order autoregressive covariance structure within parity. Because the different classes for BAC and BAC quantity were relatively well-balanced across the effects (line, sampling time, and year) the linear models hold, no specific models needed to be fitted for binary traits and the same model structure could be used as for the continuous traits.

For the dependent variables FEC (log-transformed) and PCV measured in second lactation, the fixed effects were line, challenge (first vs. second), and sampling time after challenge ( 3 for FEC and 5 for PCV). The correlated structure of data arising from longitudinal measurements ( 3 to 5 sampling time points) on successive challenges (first and second) was fitted with a direct product first-order autoregressive covariance structure within parity. The 2 groups of high- and lowSCS goats selected for the experiment were also tested 
for different SCS levels and whether the challenge had an effect on SCS by applying the mixed model [1] for the dependent variable SCS in this data set. The fixed effects tested were sampling time point, line, and their interaction. Next, the fixed effects were replaced by line, period (challenge period $=2$ sampling dates; out of challenge period $=7$ sampling time points), and their interaction. We used 9 sampling time points each with 37 to 40 observations.

Statistical differences between the lines for instantaneous infectious rate with specific bacterial species were assessed by applying exact Fisher tests (PROC FREQ, SAS Institute Inc.). Pearson correlation coefficients were estimated with SAS (PROC CORR, SAS Institute Inc.).

\section{RESULTS}

\section{Difference Between Lines for Milk Production Traits and SCS}

Milk production traits, including milk quantity, FC, and PC, were similar in both lines, whereas large differences in SCC and SCS were observed (Table 2). Analysis of variance showed a significant line effect on SCS, which corresponded to raw milk SCC that were almost doubled between the lines, with 1,542,000 versus 855,000 cells/mL in the high- and low-SCS lines, respectively (Table 2). The LSCS EBV, based on data from the first 3 lactations, were $90.4( \pm 5.5)$ and 106.9 $( \pm 5.2)$ in the high- and low-SCS goats, respectively. The difference $(P<0.001)$ between the offspring from the 2 lines was therefore equal to 1.65 equivalent genetic standard deviations (16.5/10). Parity significantly affected SCS, with an increase in SCS least squares means $( \pm \mathrm{SE})$ from $4.56( \pm 0.09), 5.33( \pm 0.11)$, to 5.73
$( \pm 0.12)$ from first to third parity; SCS also increased with lactation stage (Figure 1). The difference $(P<$ 0.001) between lines, however, was similar across lactation stage and parity without any systematic increase or decrease trend, except at the first sampling time point after kidding, for which the standard errors were higher (Figure 1).

\section{Difference Between Lines for BAC and Mastitis}

Milk bacteriological analyses were carried out on 2,688 samples from healthy goats or goats with nonacute mastitis. Among them $42.5 \%$ were positive. The bacteria most frequently isolated were staphylococci (Table 3). Among them, the most frequent were $S$. xylosus, S. caprae, S. epidermidis, S. simulans, and $S$. aureus representing 18.9, 17.6, 12.7, 7.0, and $4.7 \%$ of the positive samples, respectively. Streptococci and $B a-$ cillus accounted for 6.6 and $8.9 \%$ of positive samples, respectively.

As indicated in Table 2, the frequency of positive samples (BAC) was significantly higher in the high-SCS line $(49 \%)$ than in the low-SCS line (33\%). The distribution of bacterial species within the positive samples was comparable between lines (Table 3). Frequency of the most often isolated staphylococci (S. xylosus, S. caprae, $S$. epidermidis, and $S$. aureus), was significantly higher in the high-SCS than in the low-SCS line (Table 3), with the highest odds ratio of 3.49 (95\% CI: 11.95-6.25) for $S$. aureus. A similar trend was observed for streptococci, although the difference between lines was not significant $(P=0.18)$. No difference between lines was observed for the frequency of positive Bacillus samples. The average amount of bacteria in positive samples, and thus the severity of infection, was also significantly higher in high- than in low-SCS goats (Table 2), which

Table 2. Descriptive statistics for the 158 high- and 129 low-SCS divergent goat lines and ANOVA testing for the difference between lines

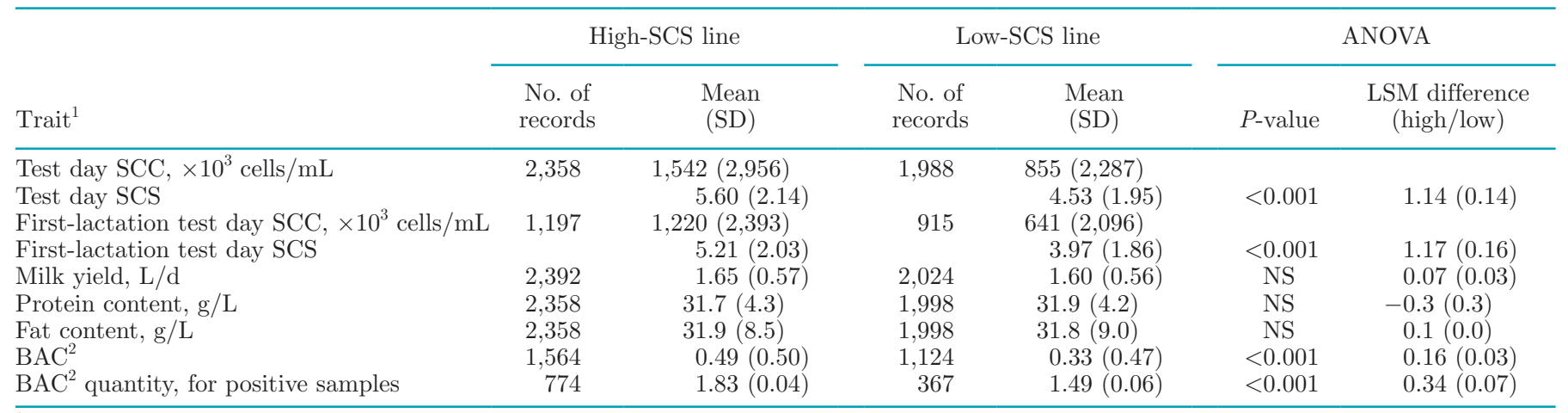

${ }^{1}$ Results from morning milking samples collected from kidding up to 270 DIM during the first 3 lactations.

${ }^{2} \mathrm{BAC}=$ positive (1) or negative (0) bacteriological milk examination result. For positive samples, a rough quantification of bacteria in positive samples wasbased on number of colonies: few (1), moderate (2), and numerous (3). 


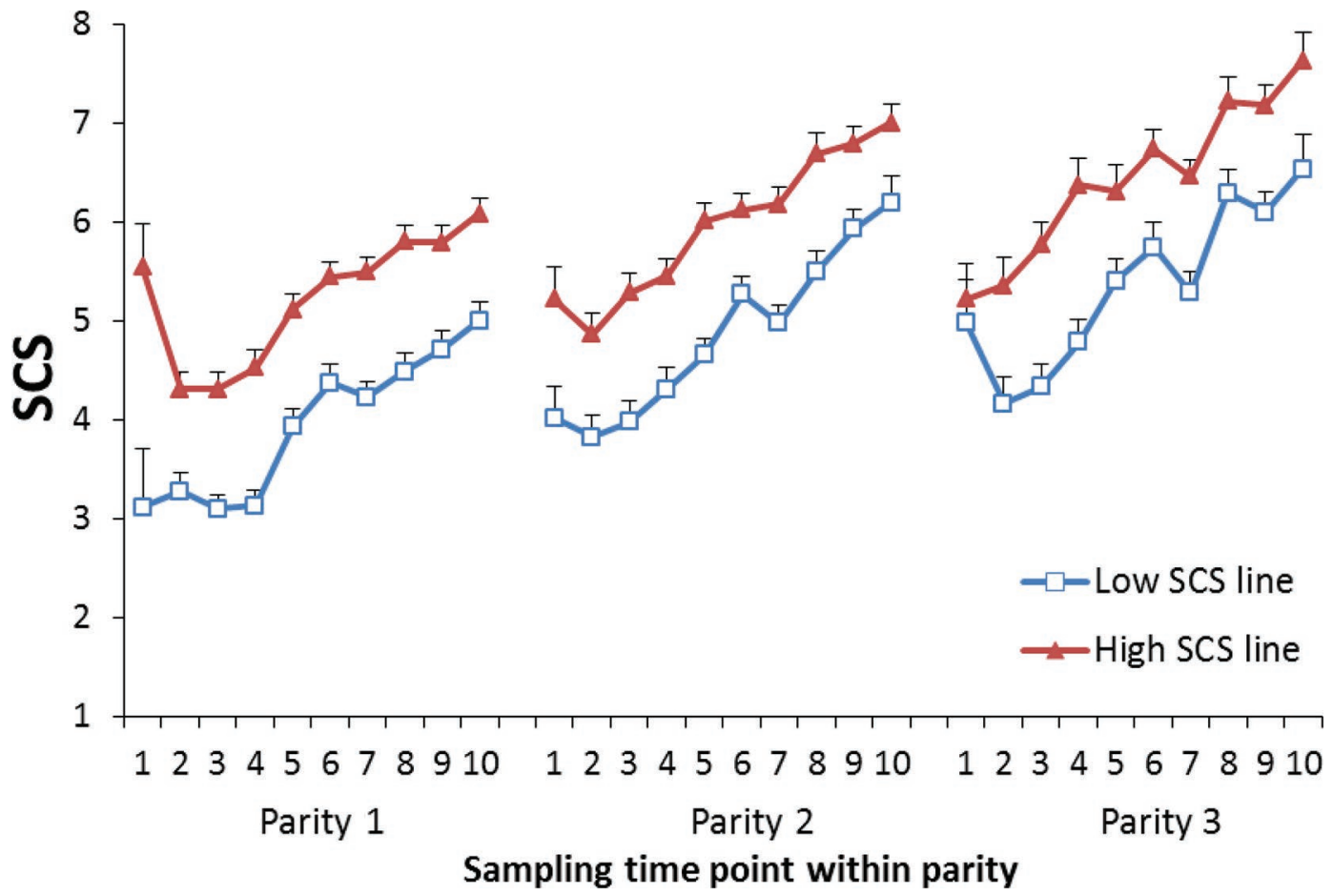

Figure 1. Somatic cell score profile (LSM $\pm \mathrm{SE}$ ) from first to third lactation in the 158 high- and 129 low-SCS divergent lines goats. Least squares means were from a mixed model including the fixed effect of line by sampling time by parity combination and then random animal effect.

Table 3. Milk bacteriological results for the 2 high- and low-SCS divergent lines ${ }^{1}$

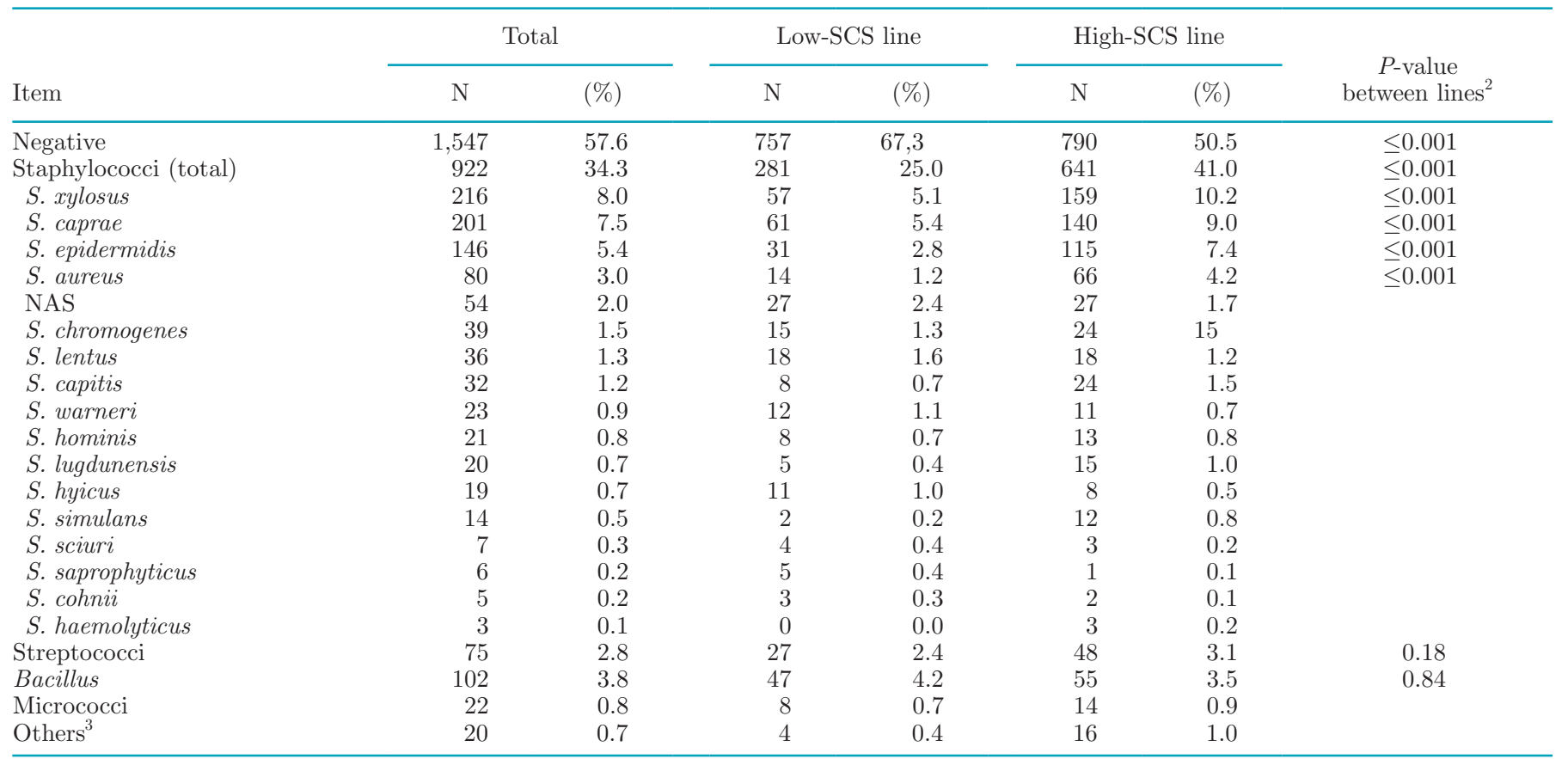

${ }^{1}$ Results were from 2,688 samples from 9 sampling time points per udder half during first lactation.

${ }^{2} P$-value from Fisher exact test (PROC FREQ, SAS version 9.4, SAS Institute Inc., Cary, NC) computed for the main bacteria species ( $\geq 2.5 \%$ ).

${ }^{3}$ Others: Acinetobacter $(\mathrm{n}=2)$, Aerococcus $(\mathrm{n}=7)$, Aspergillus $(\mathrm{n}=2)$, Corynebacterium $(\mathrm{n}=3)$, Escherichia coli $(\mathrm{n}=3)$, Pseudomonas $(\mathrm{n}=$ $2)$, yeast $(\mathrm{n}=1)$. 


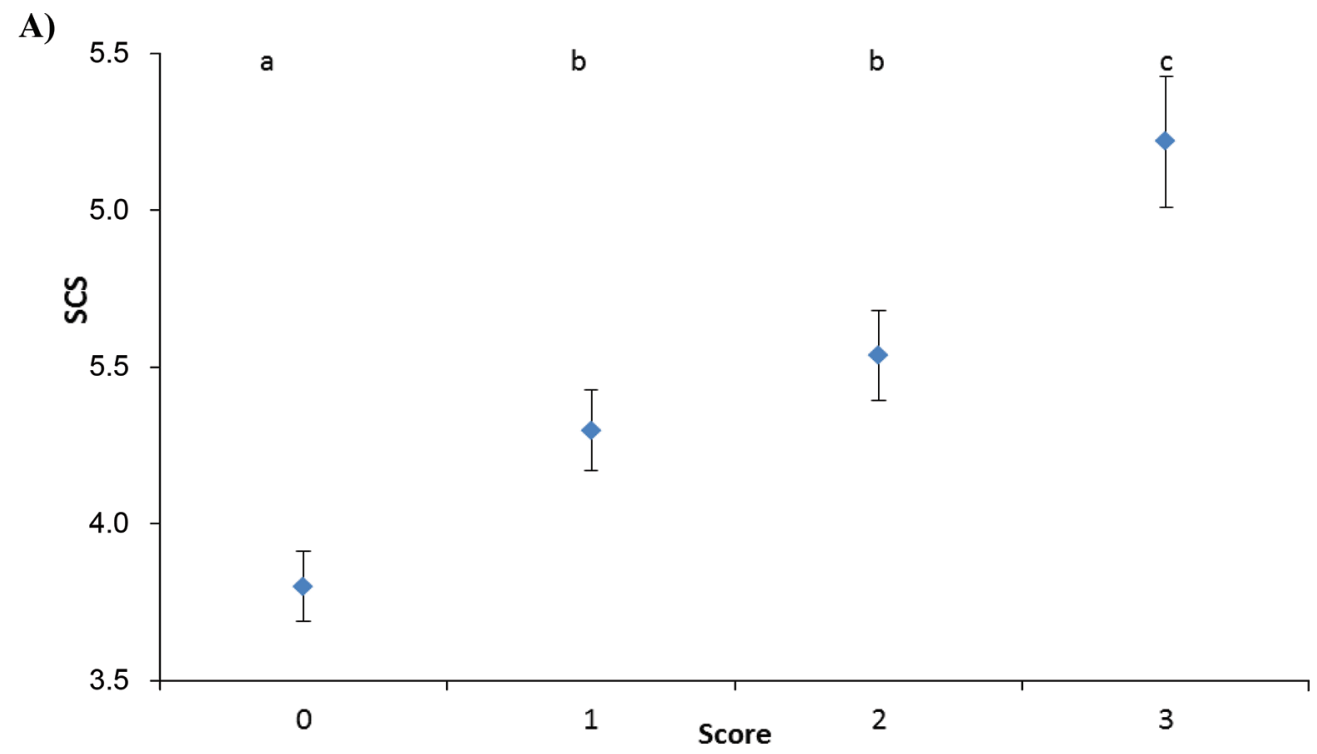

B)

\begin{tabular}{|c|c|c|c|c|}
\hline & & & $\begin{array}{l}\text { One udder half positive } \\
\text { BAC quant }<100 \\
\text { S. aureus }\end{array}$ & $\begin{array}{c}\text { One udder half positive } \\
\text { BAC quant }>100 \\
\text { S. aureus }\end{array}$ \\
\hline & $\begin{array}{l}\text { Two negative } \\
\text { udder halves }\end{array}$ & $\begin{array}{l}\text { One udder half positive } \\
\text { BAC quant }<100 \\
\text { No } S \text {. aureus }\end{array}$ & $\begin{array}{c}\text { One udder half positive } \\
\text { BAC quant }>100 \\
\text { No } S . \text { aureus }\end{array}$ & $\begin{array}{c}\text { Two udder halves } \\
\text { positive } \\
\text { BAC quant }<100 \\
\text { S. aureus }\end{array}$ \\
\hline C) & & & $\begin{array}{l}\text { Two udder halves } \\
\text { positive } \\
\text { BAC quant }<100 \\
\text { No } S \text {. aureus }\end{array}$ & $\begin{array}{l}\text { Two udder halves } \\
\text { positive } \\
\text { BAC quant }>100 \\
\text { No } S \text {. aureus } \\
\text { Two udder halves } \\
\text { positive } \\
\text { BAC quant }>100 \\
\text { S. aureus }\end{array}$ \\
\hline High SCS & 236 & 216 & 202 & 130 \\
\hline Low SCS & 278 & 170 & 82 & 33 \\
\hline
\end{tabular}

Figure 2. (A) Somatic cell score value ( $\mathrm{LSM} \pm \mathrm{SE}$ ) according to the bacteriological status of the udder gland (score). The letters (a-c) show significant differences. Significant differences were determined by $t$-test at $P<0.001$ from a mixed model including sampling time by year as fixed effects and animal as random effect. (B) Definition of the bacteriological status of the udder gland (score); scores 2 and 3 are defined by alternative conditions. (C) Frequency of udder glands according to score and genetic line. S. aureus = Staphylococcus aureus; BAC $=$ bacterial milk examination.

corresponded to an average of $69( \pm 80)$ versus $38( \pm 62)$ growing colonies, respectively.

The infection and SCS in the divergent lines were further quantified by classifying the udders according to the presence and severity of infections on a sampling date basis. The classification into healthy glands or mild and severe infection was strongly associated with the SCS (Figure 2). This agreed with the correlation between the udder half test-day SCS with BAC and BAC quantity (in positive samples), which was 0.40 and 0.38 , respectively. Furthermore, the frequency of udder glands with the most severe infections (score $=$ 3 , associated with the presence of $S$. aureus or a large quantity of bacteria in milk) was higher in the highSCS line (16.5\%) than in the low-SCS (6\%) line.

Special attention was given to goats with very few culture-positive samples. The question was whether healthy goats have low, average, or high SCC. For $20 \%$ of the animals ( $\mathrm{n}=35$ animals and 526 samples), milk was culture positive in less than 1 out of 5 of their udder half milk samples. The average SCC in those animals was especially low (i.e., equal to 278,000 cells $/ \mathrm{mL} \pm$ 
$1,080,000)$ when compared with the average (i.e., equal to $1,014,000$ cells $/ \mathrm{mL} \pm 3,165,000 ; \mathrm{n}=176$ animals with 2,245 samples). Out of these 35 healthy animals, 7 and 14 were in the high- and low-SCS lines respectively.

Only 7 cases of clinical mastitis were recorded in the 287 goats between 2009 and 2016. These cases were equally distributed between the high- $(\mathrm{n}=4 ; 2.5 \%)$ and low-SCS $(\mathrm{n}=3 ; 2.3 \%)$ lines.

\section{Difference Between Lines for Response to Challenge with $H$. contortus}

Figure 3 shows FEC and PCV upon challenge with $H$. contortus. The challenge elicited a strong significant decrease in PCV, which remained low during the second challenge. Inversely, FEC increased to an average of $1,750( \pm 142)$ and $1,460( \pm 170)$ at $d 35$ after the first and second challenge, respectively. We found no difference between the genetic lines, with similar response patterns for high- and low-SCS goats. A significant difference in SCS of $1.48 \pm 0.34$ between the genetic lines was observed in the goats selected for the experimental challenge with $H$. contortus $(\mathrm{n}=2 \times 20)$. This difference was slightly higher than in the overall experimental population measured over lactations 1 to $3(1.14 \pm 0.14$; Table 2$)$. This divergence between lines was observed from the first milk control onwards (Supplemental Figure S1; https://doi.org/10.3168/jds .2018-15664). The challenge with $H$. contortus had no significant effect on SCS.

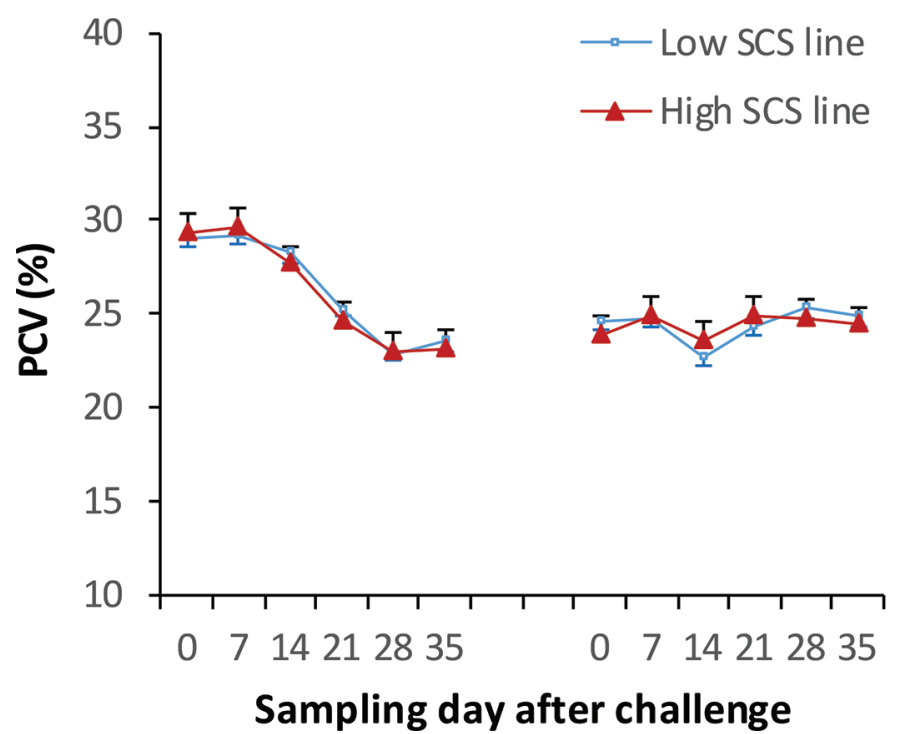

\section{DISCUSSION}

\section{Relationship Between SCC and Bacteria in Goat Milk}

The present study provides further evidence that milk SCC is related to subclinical mastitis in goats. A clear positive correlation was observed between the SCC and the presence of bacteria in milk, these being mainly staphylococci (S.xylosus, S. caprae, S. epidermidis, and $S$. simulans) in the present study. The amounts of bacteria in milk increased as the SCS level increased. Conversely, goats with repeatedly negative udders $(80 \%$ of negative milk samples) exhibited the lowest levels of SCC, with an average of 277,000 cells/mL. Milk SCC has been widely used in dairy ruminants as a proxy to predict IMI. Indeed, milk SCC mainly reflects the number of neutrophils that migrate from blood to the mammary gland in response to infection. As with dairy cattle and sheep, an increased SCC in goats has been reported as a consequence of infection (Poutrel et al., 1997; Paape et al., 2001; Bergonier et al., 2003; Luengo et al., 2004; Moroni et al., 2005; Koop et al., 2010). Based on milk bacteriology examination, Contreras et al. (1996) considered that a value of 500,000 cells/ $\mathrm{mL}$ was a useful threshold to discriminate infected and uninfected udder halves. Based on prediction guidelines involving repeated SCC measures over a given lactation, De Crémoux and Poutrel (2001) suggested measuring several SCC during lactation and 2 thresholds of 750,000 and 1,750,000 cells/mL to discriminate 3 statuses: uninfected animals, animals infected with

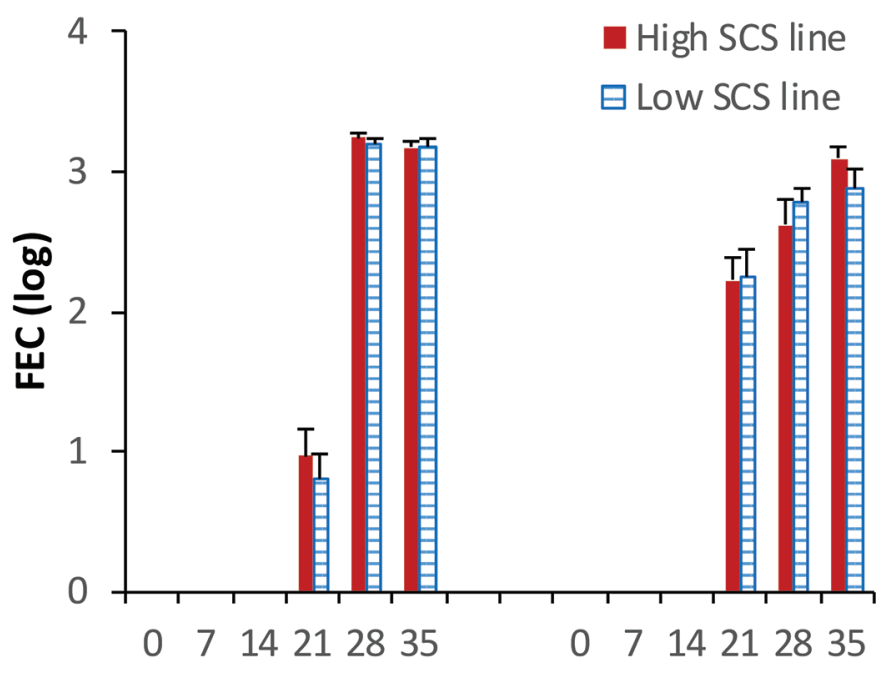

\section{Sampling day after challenge}

Figure 3. Packed cell volume (PCV) and fecal egg count (FEC; log-transformed) profiles (LSM \pm SE) in 20 high- and 20 low-SCS goats challenged twice with Haemonchus contortus at approximately 90 DIM and 140 DIM. Least squares means were from a mixed model including the fixed effect of line, challenge (first vs. second), sampling time after challenge, and then random animal effect. 
minor pathogens, and animals infected with major pathogens. Those authors obtained sensitivities of 61 to $83 \%$ and specificities of 61 to $80 \%$ depending on the status; however, the ability of milk SCC to predict IMI in goats is often considered poorer than in cattle and sheep (Poutrel and Lerondelle, 1983; Boettcher et al., 2005), due mainly to the elevated values reported in goats as compared with dairy ewes and cows. For instance, the average values of LSCS (first lactations) were $2.6 \pm 1.2$ in Holstein (Rupp and Boichard, 1999), $3.1 \pm 1.5$ in Lacaune sheep (Rupp et al., 2003), and $5.34 \pm 1.59$ in Alpine goats (data from 405,004 primiparous Alpine goats in the national database; IDELE, 2018). The prevalence of IMI and the type of pathogens (mainly staphylococci) were similar in all 3 dairy species, except that the frequency of clinical mastitis due to streptococci and Escherichia coli is higher in dairy cattle (Bergonier et al., 2003). High SCC levels in goats are probably due, at least to some extent, to the importance of lentiviral infection and to noninfectious factors of inflammation, such as parity, stage of lactation, or season (Paape et al., 2001; Bergonier et al., 2003; Luengo et al., 2004; Moroni et al., 2005; Koop et al., 2010). These factors are therefore presumed to mask the link between SCC and udder bacterial infection, and the distribution of SCC between infected and noninfected animals is thought to overlap considerably. In the present study, we confirmed that SCS is a good predictor of IMI and the hygienic quality of milk. The cell counts in goats with a low frequency of bacteria in milk were below 300,000 cells $/ \mathrm{mL}$. Though imperfect, SCC can thus efficiently be used for prophylactic purposes, including the culling of persistently infected animals.

\section{Response to SCS-Based Selection on Udder Health in Goats}

By using a set of 60 AI bucks with extreme breeding values for SCS, we managed to breed 2 groups of goats with a large difference in SCC equal to 1.14 scoring points (raw data) and 1.65 genetic standard deviation (EBV). The experiment was a 1-generation divergent experiment, as bucks were selected each year within the national population. The response was in agreement with the selection intensity and heritability $\left(\mathrm{h}^{2}=\right.$ 0.20) of the trait (Rupp et al., 2011). The surveillance of 287 goats from the high- and low-SCS lines over 3 lactations suggested favorable responses to SCS-based selection on milk quality and on resistance to mastitis. Indeed, the frequency of positive bacteriology samples was significantly higher in the high- $(49 \%)$ versus low$(33 \%)$ SCS line. In addition, the amount of bacteria in positive samples from the high-SCS line was also higher than in positive samples from the low line. Thus, milk hygienic quality was notably improved in low-SCS compared with high-SCS goats. Part of the sample positivity might be due to transitory infections or colonization of the teat rather than to infection established upper in the mammary gland. However, because the bacterial results were well correlated with SCC, the hypothesis of established infection holds for most of the large number of samples analyzed $(>2,500)$. Clinical mastitis was rare, as usually reported in goats (Bergonier et al., 2003), which would preclude the evaluation of a possible selection effect. The clinical cases in high- and low-SCS lines also occurred at random. The data therefore suggest a favorable reduction in the incidence and duration of IMI and control of bacterial multiplication in goats selected for low SCS. Results also suggested that the distribution of pathogen species did not differ between the lines and that the risk of mastitis was not higher in low-SCS goats than in high-SCS goats. This responds to the controversy about selecting for excessively low milk SCC in dairy species, discussed by Rainard et al. (2018a). At least within the range of observed values, and given the strong selection intensity, goats genetically selected for low SCS showed the best milk quality and best mastitis bacteria control under natural conditions of infection.

The results from our study were in close agreement with those from a similar divergent selection experiment conducted in Lacaune dairy sheep (Rupp et al., 2009). The SCS differed significantly in high- (4.48) and low- (2.90) SCS groups primiparous dairy ewes, as did the incidence of positive bacteriology (39 and 12\%, respectively). Comparison with the present results in goats revealed an almost perfect linear relationship across the 2 experiments (and species) between the SCS and the infection rate. This suggests that the frequency of positive samples can be directly predicted from SCS under different breeding conditions. It also suggests that the high SCC in goats is mainly due to higher infection rates. Rupp et al. (2009) concluded that the better resistance of low-SCS ewes, as compared with high-SCS ewes, was principally characterized by "a better ability to limit IMI during the peripartum period, to eliminate IMI during lactation, and quantitatively limit the inflammation process (and its clinical consequences)."

Although similar conclusions can be drawn here, the underlying mechanisms that were selected are still mostly unknown and could be multiple in nature. LowSCS goats may better control the number of bacteria that enter the mammary gland through better first-line defense mechanisms in the teat canal. Better emptying 
of the udder gland at milking, due to efficient milk emission properties, might also help to control infection. Low-SCS goats might also exhibit a more efficient or rapid immune response, thereby limiting the multiplication of bacteria or the inflammation process. Direct extrapolation to goats is not straightforward, however; indeed, experimental infections were conducted in a limited number of goats $(\mathrm{n}=10)$ from the present divergent lines in 2 independent studies (Cremonesi et al., 2012; Rainard et al., 2018b). The results from both of those studies did not reveal any difference in SCC, bacterial count, or gene expression patterns upon challenge with $S$. aureus. Disentangling the different components responsible for better resistance or milk quality in low-SCS goats thus requires further investigation.

\section{Genetic Link Between Resistance to Nematodes and Resistance to Bacteria in Goat}

Goats were susceptible to the experimental infestation with $H$. contortus and became anemic (PCV around $22-24 \%$ ) and exhibited high egg counts (>1,400 eggs per gram of feces) at 3 to 4 wk after infestation. The anemia profiles after first challenge were similar to those observed in Creole kids (Bambou et al., 2013); FEC and anemia after the second challenge were higher in our adult lactating goats. The clear degree of protection, reported in Creole kids previously infected with $H$. contortus, was not observed in the current study. Goats showed a variable interindividual response upon challenge, as the coefficient of variation for FEC ranged from 6 to $11 \%$ (d 21-35); however, there was no difference between the genetic lines. To our knowledge, no data have been published on a possible genetic relationship between resistance to mastitis and resistance to nematodes in ruminants. The results presented herein suggest that genetic resistance to mastitis and gastrointestinal infections are under independent genetic regulation. Selection for low SCC and decreased IMI should therefore not affect the animal's ability to cope with gastrointestinal nematodes.

\section{Can These Results be Extended to Field Situations?}

These results were observed in a single experimental herd and in a single breed (Alpine); however, the production, epidemiological, and etiological situation of the herd were within the commercial dairy goat herd range. Indeed, according to the national database, the average milk production over $250 \mathrm{~d}$ is $956 \mathrm{~kg}( \pm 299)$ for a total of 851,924 Alpine lactations with a parity of 1 to 3 . Milk production in the present study was $1.62 \mathrm{~L} / \mathrm{d}$ $(1.67 \mathrm{~kg} / \mathrm{d})$, at the morning milking, which corresponds to an average of $841 \mathrm{~kg}$ on a $250-\mathrm{d}$ basis $[1.67 \times 1.55 / \mathrm{d}$ $\times 250 \mathrm{~d} \times 1.3$ (adult equivalent)]. The average LSCS in 405,004 primiparous Alpine goats was $5.34( \pm 1.59)$ in the national database compared with $4.67( \pm 2.05)$ herein. The experimental herd therefore exhibited similar, although slightly lower, values of SCS and milk production than reported in the large field data set. The high-SCS line exhibited the SCS and SCC values commonly observed on the farm. Regarding mastitis, similar frequencies of clinical mastitis (less than 5\%) and clinical or subclinical IMI etiology to the present study were reported in the review by Bergonier et al. (2003) based on large-scale surveys in European goat breeds. Others reported similar SCS levels and varying prevalence (15-80\%) of subclinical mastitis in Indian (Mishra et al., 2018), Spanish (Contreras et al., 1999), or Chinese goats (Zhao et al., 2015). In general, previous studies have reported the definite predominance of CNS, such as $S$. epidermidis and $S$. chromogenes, as causal agents of subclinical and often chronic mastitis.

\section{Implementation in the French Dairy Goat Breeding Objectives}

The experimental design enabled us to create a large difference in SCS between the high and low lines. Routine genetic evaluations for SCC are now performed in Alpine and Saanen breeds in France, as goat breeders have benefitted from long-term records of SCC in the milk recording system. From 2014 onward, LSCS has been included in the selection index used for planned matings so as to produce AI sires in the selection nucleus. Breeders have chosen to place a weight of 17 and $12 \%$ on SCS in Saanen and Alpine breed, respectively, in addition to udder traits and production in the total merit index. Accordingly, the genetic change to be expected in $10 \mathrm{yr}$ is +0.34 genetic standard deviations in Alpine. The observations reported here, therefore, provide additional information on the likely long-term effects and efficacy of on-farm SCS-based selection regarding IMI, despite the limit of the small size of the experimental design.

\section{CONCLUSIONS}

Divergent selection based on EBV for SCS of AI bucks allowed creating 2 groups of goats with strongly divergent SCS. Monitoring of the lines indicated that SCS-based selection helps to improve udder health by decreasing milk cell counts and reducing the incidence and quantity of bacteria in milk. Selection for better mastitis resistance had no adverse effect on resistance to gastrointestinal nematodes. The results supported the 
breeders' decision to include the trait in the breeding objectives for French Alpine and Saanen breeds. Our experimental design should allow further investigations of host mechanisms, leading to improved resistance to mastitis in goats.

\section{ACKNOWLEDGMENTS}

The authors thank the staff of the INRA experimental unit at Bourges for technical support in producing, raising, and monitoring the animals. This work was supported by grants from the Centre Region, France (CAPRICEL and CAPRIMAM), and a Compte d'affection Spécial au Développement Agricole et Rural (CASDAR; Paris, France) project (MAMOVICAP).

\section{REFERENCES}

Ali, A. K. A., and G. E. Shook. 1980. An optimum transformation for somatic cell concentration in milk. J. Dairy Sci. 63:487-490. https: //doi.org/10.3168/jds.S0022-0302(80)82959-6.

Bambou, J. C., T. Larcher, W. Ceï, P. J. Dumoulin, and N. Mandonnet. 2013. Effect of experimental infection with Haemonchus contortus on parasitological and local cellular responses in resistant and susceptible young Creole goats. BioMed Res. Int. 2013:902759. https://doi.org/10.1155/2013/902759.

Bergonier, D., R. de Crémoux, R. Rupp, G. Lagriffoul, and X. Berthelot. 2003. Mastitis of dairy small ruminants. Vet. Res. 34:689-716. https://doi.org/10.1051/vetres:2003030.

Boettcher, P. J., P. Moroni, G. Pisoni, and D. Gianola. 2005. Application of a finite mixture model to somatic cell scores of italian goats. J. Dairy Sci. 88:2209-2216. https://doi.org/10.3168/jds .S0022-0302(05)72896-4.

Chartier, C., F. Soubirac, I. Pors, A. Silvestre, J. Hubert, C. Couquet, and J. Cabaret. 2001. Prevalence of anthelmintic resistance in gastrointestinal nematodes of dairy goats under extensive management conditions in southwestern France. J. Helminthol. 75:325330.

Contreras, A., M. J. Paape, and R. H. Miller. 1999. Prevalence of subclinical intramammary infection caused by Staphylococcus epidermidis in a commercial dairy goat herd. Small Rumin. Res. 31:203-208. https://doi.org/10.1016/S0921-4488(98)00147-3.

Contreras, A., D. Sierra, J. C. Corrales, A. Sanchez, and J. Marco. 1996. Physiological threshold of somatic cell count and California Mastitis Test for diagnosis of caprine subclinical mastitis. Small Rumin. Res. 21:259-264. https://doi.org/10.1016/0921 $-4488(95) 00827-6$.

Contreras, A., D. Sierra, A. Sánchez, J. C. Corrales, J. C. Marco, M. J. Paape, and C. Gonzalo. 2007. Mastitis in small ruminants. Small Rumin. Res. 68:145-153. https://doi.org/10.1016/j.smallrumres .2006.09.011

Crawley, A. M., B. Mallard, and B. N. Wilkie. 2005. Genetic selection for high and low immune response in pigs: Effects on immunoglobulin isotype expression. Vet. Immunol. Immunopathol. 108:71-76. https://doi.org/10.1016/j.vetimm.2005.07.006.

Cremonesi, P., R. Capoferri, G. Pisoni, M. Del Corvo, F. Strozzi, R. Rupp, H. Caillat, P. Modesto, P. Moroni, J. L. Williams, B. Castiglioni, and A. Stella. 2012. Response of the goat mammary gland to infection with Staphylococcus aureus revealed by gene expression profiling in milk somatic and white blood cells. BMC Genomics 13:540. https://doi.org/10.1186/1471-2164-13-540.

Davies, G., S. Genini, S. C. Bishop, and E. Giuffra. 2009. An assessment of opportunities to dissect host genetic variation in resistance to infectious diseases in livestock. Animal 3:415-436. https://doi .org/10.1017/S1751731108003522.
De Crémoux, R., and B. Poutrel. 2001. Somatic cell count in goats milk: A tool in presumptive diagnosis of intramammary infections. Pages 757-760 7th International Conference on Goats, Tours, France. L. Gruner and Y. Chabert, ed. Institut d'Elevage and INRA, Paris, France.

Duboeuf, J.-P., P. Mohrand-Fehr, and R. Rubino. 2004. Situation, changes and future of goat industry around the world. Small Rumin. Res. 51:165-173.

Heringstad, B., G. Klemetsdal, and J. Ruane. 2000. Selection for mastitis resistance in dairy cattle: A review with focus on the situation in the Nordic countries. Livest. Sci. 64:95-106. https://doi.org/10 .1016/S0301-6226(99)00128-1.

IDELE (Institut de L'Elevage). 2018. Productions caprines lait et viande. http://idele.fr/filieres/publication/idelesolr/recommends/ chiffres-cles-caprins-2018.html.

Jiménez-Granado, R., M. Sánchez-Rodríguez, C. Arce, and V. Rodríguez-Estévez. 2014. Factors affecting somatic cell count in dairy goats: a review. Span. J. Agric. Res. 12:133-150. https://doi.org/ 10.5424/sjar/2014121-3803.

Koop, G., N. Dik, M. Nielen, and L. J. A. Lipman. 2010. Short communication: Repeatability of differential goat bulk milk culture and associations with somatic cell count, total bacterial count, and standard plate count. J. Dairy Sci. 93:2569-2573. https://doi.org/ 10.3168/jds.2009-2705.

Lacroux, C., T. H. Nguyen, O. Andreoletti, F. Prevot, C. Grisez, J. P. Bergeaud, L. Gruner, J. C. Brunel, D. Francois, P. Dorchies, and P. Jacquiet. 2006. Haemonchus contortus (Nematoda: Trichostrongylidae) infection in lambs elicits an unequivocal Th2 immune response. Vet. Res. 37:607-622.

Larroque, H., J.-M. Astruc, A. Barbat, F. Barillet, D. Boichard, B. Bonaiti, V. Clément, I. David, G. Lagriffoul, and I. Palhiere. 2011. National genetic evaluations in dairy sheep and goats in France. Page 62 in Annual Meeting of the European Federation of Animal Science (EAAP). Wageningen Academic Publishers, Wageningen, the Netherlands.

Luengo, C., A. Sánchez, J. C. Corrales, C. Fernández, and A. Contreras. 2004. Influence of intramammary infection and non-infection factors on somatic cell counts in dairy goats. J. Dairy Res. 71:169-174.

Miglior, F., B. L. Muir, and B. J. Van Doormaal. 2005. Selection indices in Holstein cattle of various countries. J. Dairy Sci. 88:12551263. https://doi.org/10.3168/jds.S0022-0302(05)72792-2.

Mishra, A. K., N. Sharma, D. D. Singh, K. Gururaj, C. Abhishek, V. Kumar, and D. K. Sharma. 2018. Prevalence and bacterial etiology of subclinical mastitis in goats reared in organized farms. Vet. World 11:20-24. https://doi.org/10.14202/vetworld.2018.20-24.

Moroni, P., G. Pisoni, G. Ruffo, and P. J. Boettcher. 2005. Risk factors for intramammary infections and relationship with somatic-cell counts in Italian dairy goats. Prev. Vet. Med. 69:163-173. https:/ /doi.org/10.1016/j.prevetmed.2004.10.013.

Mouton, D., Y. Bouthillier, J. C. Mevel, and G. Biozzi. 1984. Genetic selection for antibody responsiveness in mice: Further evidence for inverse modification of macrophage catabolic activity without alteration of the expression of T-cell-mediated immunity. Ann. Immunol. (Paris) 135D:173-186.

Paape, M. J., B. Poutrel, A. Contreras, J. C. Marco, and A. V. Capuco. 2001. Milk somatic cells and lactation in small ruminants. J. Dairy Sci. 84(E. Suppl.):E237-E244. https://doi.org/10.3168/jds .S0022-0302(01)70223-8.

Pinard-van der Laan, M.-H. 2002. Immune modulation: the genetic approach. Vet. Immunol. Immunopathol. 87:199-205.

Poutrel, B., R. de Crémoux, M. Ducelliez, and D. Verneau. 1997. Control of intramammary infections in goats: impact on somatic cell counts. J. Anim. Sci. 75:566-570.

Poutrel, B., and C. Lerondelle. 1983. Cell content of goat milk: California Mastitis Test, Coulter counter, and Fossomatic for predicting half infection. J. Dairy Sci. 66:2575-2579. https://doi.org/10 .3168/jds.S0022-0302(83)82129-8.

Rainard, P., G. Foucras, D. Boichard, and R. Rupp. 2018a. Invited review: Low milk somatic cell count and susceptibility to mastitis. J. Dairy Sci. 101:6703-6714. https://doi.org/10.3168/jds.2018-14593. 
Rainard, P., C. Gitton, T. Larcher, T. Fassier, C. Huau, M. R. Aurel, G. Tosser-Klopp, Z. Krupova, A. Chaize, F. B. Gilbert, R. Rupp, and P. Martin. 2018b. Host factors determine the evolution of infection with Staphylococcus aureus to gangrenous mastitis in goats. Vet. Res. 49:72. https://doi.org/10.1186/s13567-018-0564-4.

Raynaud, J.-P., G. William, and G. Brunault. 1970. Etude de l'efficacité d'une technique de coproscopie quantitative pour le diagnostic de routine et le contrôle des infestations parasitaires des bovins, ovins, équins et porcins. Ann. Parasitol. Hum. Comp. 45:321-342. https://doi.org/10.1051/parasite/1970453321.

Rupp, R., D. Bergonier, S. Dion, M. C. Hygonenq, M. R. Aurel, C. Robert-Granié, and G. Foucras. 2009. Response to somatic cell count-based selection for mastitis resistance in a divergent selection experiment in sheep. J. Dairy Sci. 92:1203-1219. https://doi .org/10.3168/jds.2008-1435.

Rupp, R., and D. Boichard. 1999. Genetic parameters for clinical mastitis, somatic cell score, production, udder type traits, and milking ease in first lactation Holsteins. J. Dairy Sci. 82:2198-2204. https: //doi.org/10.3168/jds.S0022-0302(99)75465-2.

Rupp, R. D. Boichard, A. Barbat, J. M. Astruc, G. Lagriffoul, and F. Barillet. 2002. Selection for mastitis resistance in French dairy sheep. Pages 119-122 in Proceedings of the 7th World Congress on Genetics Applied to Livestock Production, Montpellier, France. INRA, Castanet-Tolosan, France.
Rupp, R., V. Clément, A. Piacere, C. Robert-Granié, and E. Manfredi. 2011. Genetic parameters for milk somatic cell score and relationship with production and udder type traits in dairy Alpine and Saanen primiparous goats. J. Dairy Sci. 94:3629-3634. https://doi .org/10.3168/jds.2010-3694.

Rupp, R., and G. Foucras. 2010. Genetics of mastitis in dairy ruminants. Pages 183-210 in Breeding for Disease Resistance in Farm Animals. S. Bishop, R. Axford, F. Nicholas, and J. Owen, ed CABI, Wallingford, United Kingdom.

Rupp, R., G. Lagriffoul, J. M. Astruc, and F. Barillet. 2003. Genetic parameters for milk somatic cell scores and relationships with production traits in French Lacaune dairy sheep. J. Dairy Sci. 86:1476-1481. https://doi.org/10.3168/jds.S0022-0302(03)73732 $-1$.

Waller, P. J. 2006. Sustainable nematode parasite control strategies for ruminant livestock by grazing management and biological control Anim. Feed Sci. Technol. 126:277-289. https://doi.org/10.1016/j anifeedsci.2005.08.007.

Zhao, Y., H. Liu, X. Zhao, Y. Gao, M. Zhang, and D. Chen. 2015. Prevalence and pathogens of subclinical mastitis in dairy goats in China. Trop. Anim. Health Prod. 47:429-435. https://doi.org/10 .1007/s11250-014-0742-y. 